Gut, 1973, 14, 293-299

\title{
Effect of proximal gastric vagotomy on gastric acid secretion and plasma gastrin
}

\author{
C. G. CLARK, M. R. LEWIN, B. H. STAGG, AND J. H. WYLLIE \\ From the Department of Surgery, University College Hospital Medical School, London
}

SUMMARY Sixteen patients underwent proximal gastric vagotomy (highly selective vagotomy) for chronic duodenal ulceration. All were subjected to preoperative and postoperative acid secretion studies. A reduction in the secretory response to pentagastrin and abolition of the response to meat extract occurred postoperatively.

Plasma gastrin levels in response to meat extract were studied by radioimmunoassay. Basal plasma gastrin levels were unaffected by vagotomy and it was found that the plasma gastrin response to meat extract was not impaired after operation if the postoperative insulin test was positive. Only if the insulin test was negative was the amount of gastrin released by meat extract reduced.

Proximal gastric vagotomy (highly selective vagotomy) denervates the parietal cell mass and is said to preserve antral function as determined by studies of gastric motility and emptying (Wastell, MacNaughton, Colin, and Gleeson, 1971; Clarke, 1971). Little is known about the effect of vagotomy on the ability of the antrum to release gastrin. Some observations have been made on the effects of truncal vagotomy (Byrnes, Lazarus, and Young, 1970; Korman, Hansky, and Scott, 1972b; McGuigan and Trudeau, 1972) and selective vagotomy (Korman, Hansky, Coupland, and Cumberland, 1972a) but the results are conflicting. In previous studies a drainage procedure was an integral part of the operation. Proximal gastric vagotomy does not require a drainage procedure and thus affords a simpler situation in which to examine the problem.

\section{Methods}

Sixteen patients were studied-13 men and three women-all of whom had chronic duodenal ulceration. The patients were all examined before operation and 10-14 days after proximal gastric vagotomy.

After an overnight fast, a 14F gauge nasogastric tube was passed into the stomach and positioned as recommended by Hassan and Hobsley (1970). The resting juice was aspirated and discarded. Continuous aspiration was then started at $4 \mathrm{~cm} \mathrm{Hg}$ vacuum

Received for publication 12 January 1973. using a Roberts pump and the gastric juice was collected in 15-minute samples. Basal secretion was collected for one hour, but only the results obtained in the last two 15-minute periods were used for calculation (Giles and Clark, 1966). Aspiration was then stopped and $100 \mathrm{ml}$ of a commercial meat extract (Oxo) was instilled into the stomach. This solution was made by dissolving three Oxo cubes in $100 \mathrm{ml}$ distilled water and adjusting the $\mathrm{pH}$ to 7.0 with $1.0 \mathrm{M} \mathrm{NaHCO}_{3}$. The Oxo was left in the stomach for 15 minutes. It was then aspirated, and collection of gastric juice was resumed for one hour. During this period a stimulation of gastric secretion is normally observed, due to the action of endogenous gastrin released in response to Oxo in the stomach (Welbourn and Burns, 1964; Giles and Clark, 1966). Each secretion study was completed by injecting pentagastrin $(6 \mu \mathrm{g} / \mathrm{kg}$ subcutaneously) and collecting the gastric juice for a further hour.

Heparinized plasma samples were obtained during the last 15 minutes of the basal period, 15 minutes after withdrawing the Oxo from the stomach, and at 15-minute intervals thereafter for one hour. The gastrin concentrations in all plasma samples were measured using a radioimmunoassay (Wyllie, Boulos, Lewin, Stagg, and Clark, 1972).

These studies were repeated after operation, and in addition to these tests, each patient had a postoperative insulin test. After collecting basal acid secretion in the usual way for one hour, $0.15 \mathrm{IU} / \mathrm{kg}$ of soluble insulin was injected intravenously. The blood sugar was measured before, and 30 minutes 
after, this injection. A satisfactory fall occurred in every case. Acid secretion was studied for two hours after the injection of the insulin.

After noting the volume, each 15-minute sample of gastric aspirate was titrated with $0 \cdot 1 \mathrm{~N} \mathrm{NaOH}$ to the phenolphthalein endpoint. The results were expressed as milliequivalents of acid secreted per 15 minutes or per hour.

Statistical treatment of the results involved the calculation of mean values and standard errors. Where comparisons were made of results obtained before and after operation paired-sample $t$ tests were used. Comparisons between different groups of patients, eg, between insulin-negative and insulinpositive groups, were made by two-sample $t$ tests. In studying acid secretion in response to either Oxo or pentagastrin, the peak response was obtained by summing the two highest consecutive values and the total response was obtained by summing the acid secreted in the four 15-minute periods following administration of the stimulant. Similarly, the peak gastrin value was taken as the highest single value in any given test and the magnitude of the overall plasma gastrin response was studied by summing the four post-Oxo values for each test.

\section{Results}

The mean results of gastric secretion studies and plasma gastrin levels for the whole group of 16 patients are shown in figure 1 . Before operation the mean basal acid secretion was $3.96 \mathrm{~m}$-equiv/hr. After instilling Oxo into the stomach acid secretion was stimulated, and an even greater stimulation of secretion followed the injection of pentagastrin. The peak responses to Oxo and pentagastrin did not occur at the same time in different individuals and because of this fig. 1 gives a picture which underestimates the peak rates of secretion actually observed. The actual values for peak rates of secretion were used in the construction of table I which shows that the basal rate of secretion of 3.96 $\mathrm{m}$-equiv/hr was increased to a mean peak rate of $19.31 \mathrm{~m}$-equiv $/ \mathrm{hr}$ after Oxo and $38.75 \mathrm{~m}$-equiv $/ \mathrm{hr}$ after pentagastrin. After operation, the basal rate of secretion was found not to be significantly altered at $3.1 \mathrm{~m}$-equiv/hr but secretion after both Oxo and pentagastrin was very significantly reduced ( $P$ values $<0.001$ ). This reduction was seen in acid secreted in the peak half hour and in the total acid secretion.
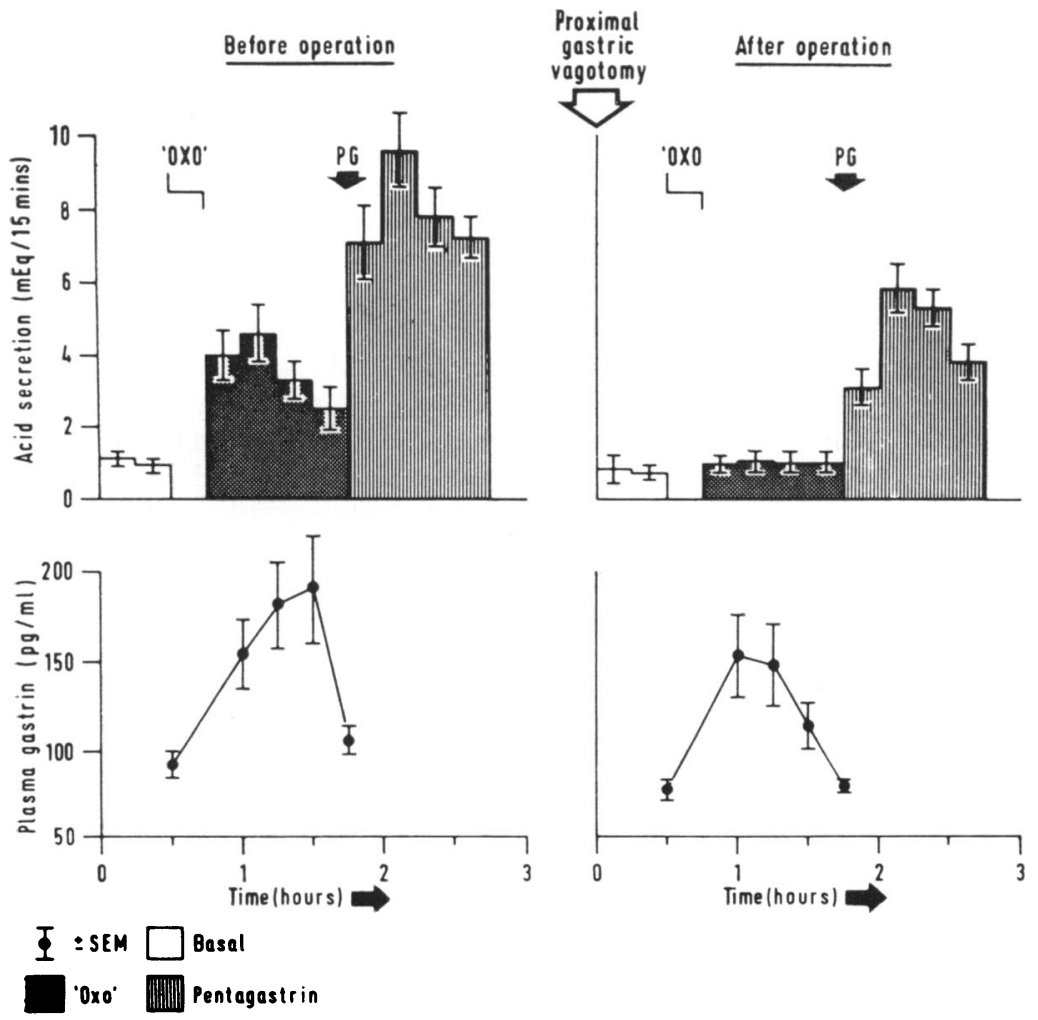

Fig. 1 Mean acid secretion and plasma gastrin levels in 16 patients before and after proximal gastric vagotomy. Acid secretion was studied in the basal state, after stimulation with $\mathrm{Oxo}$, and after stimulation with pentagastrin. The plasma gastrin response to Oxo is shown. 


\begin{tabular}{|c|c|c|c|c|c|c|}
\hline & \multicolumn{3}{|c|}{ Mean Acid Secretion (m-equiv/hr) $\pm S E M$} & \multicolumn{3}{|c|}{ Plasma Gastrin Levels $(\mathrm{pg} / \mathrm{ml}) \pm S E M$} \\
\hline & $\begin{array}{l}\text { Before } \\
\text { Operation }\end{array}$ & $\begin{array}{l}\text { After } \\
\text { Operation }\end{array}$ & $\begin{array}{l}\text { P Values }{ }^{1} \text { for } \\
\text { Pair Differences }\end{array}$ & $\begin{array}{l}\text { Before } \\
\text { Operation }\end{array}$ & $\begin{array}{l}\text { After } \\
\text { Operation }\end{array}$ & $\begin{array}{l}P \text { Values for } \\
\text { Pair Differences }\end{array}$ \\
\hline Basal & $3.96 \pm 0.70$ & $3.11 \pm 1.02$ & NS & $91 \cdot 7 \pm 7.9$ & $77 \cdot 4 \pm 6 \cdot 0$ & NS \\
\hline $\begin{array}{l}\text { Peak after Oxo } \\
\text { Total after Oxo }\end{array}$ & $\begin{array}{l}19 \cdot 31 \pm 2 \cdot 60 \\
15 \cdot 17 \pm 2 \cdot 18\end{array}$ & $\begin{array}{l}5.21 \pm 1.14 \\
3.93 \pm 1.06\end{array}$ & $\begin{array}{l}P<0.001 \\
P<0.001\end{array}$ & $\begin{array}{l}249 \cdot 6 \pm 25 \cdot 7 \\
630 \cdot 9 \pm 54 \cdot 9\end{array}$ & $\begin{array}{l}182.1 \pm 27.0 \\
493.6 \pm 52.6\end{array}$ & $\begin{array}{l}P<0.05 \\
P<0.05\end{array}$ \\
\hline $\begin{array}{l}\text { Peak after pentagastrin } \\
\text { Total after pentagastrin }\end{array}$ & $\begin{array}{l}38 \cdot 75 \pm 3.04 \\
31 \cdot 80 \pm 2 \cdot 32\end{array}$ & $\begin{array}{l}11.60 \pm 2.20 \\
18.04 \pm 1.87\end{array}$ & $\begin{array}{l}P<0.001 \\
P<0.001\end{array}$ & & & \\
\hline
\end{tabular}

Table I Results of acid secretion tests and plasma gastrin estimations in 16 patients before and after proximal gastric vagotomy

${ }^{2} \mathbf{P}$ values are calculated for one-tail $\mathrm{t}$ tests.

The mean plasma gastrin levels are shown in the lower half of fig 1 and these data are also summarized in table I. Before operation the mean value was $92 \mathrm{pg} / \mathrm{ml}$ under fasting conditions. This was elevated to a mean of $250 \mathrm{pg} / \mathrm{ml}$ after Oxo. There was considerable variation in the timing of the peak gastrin response, which occurred 15 minutes after withdrawing the Oxo in five cases, at 30 minutes in four cases, at 45 minutes in six cases, and as late as 60 minutes in one case. Apart from this last experiment the plasma gastrin responses returned to normal by one hour. Because of the variation in timing of response, the mean curve in fig 1 does not reach the peak value of $250 \mathrm{pg} / \mathrm{ml}$ shown in table $\mathrm{I}$. The preoperative fasting plasma gastrin level of $92 \mathrm{pg} / \mathrm{ml}$ was reduced following vagotomy to a level of $77 \mathrm{pg} / \mathrm{ml}$ but this difference was not significant. However, the plasma gastrin response to Oxo was demonstrably reduced by operation. The mean peak value of $250 \mathrm{pg} / \mathrm{ml}$ before operation fell to 182 $\mathrm{pg} / \mathrm{ml}$ afterwards $(\mathrm{P}<0.05)$ and when all the postOxo values were added for each case (to give an idea of the magnitude of the overall gastrin response) this also showed a reduction significant at the $5 \%$ level.

These results for the whole series of patients

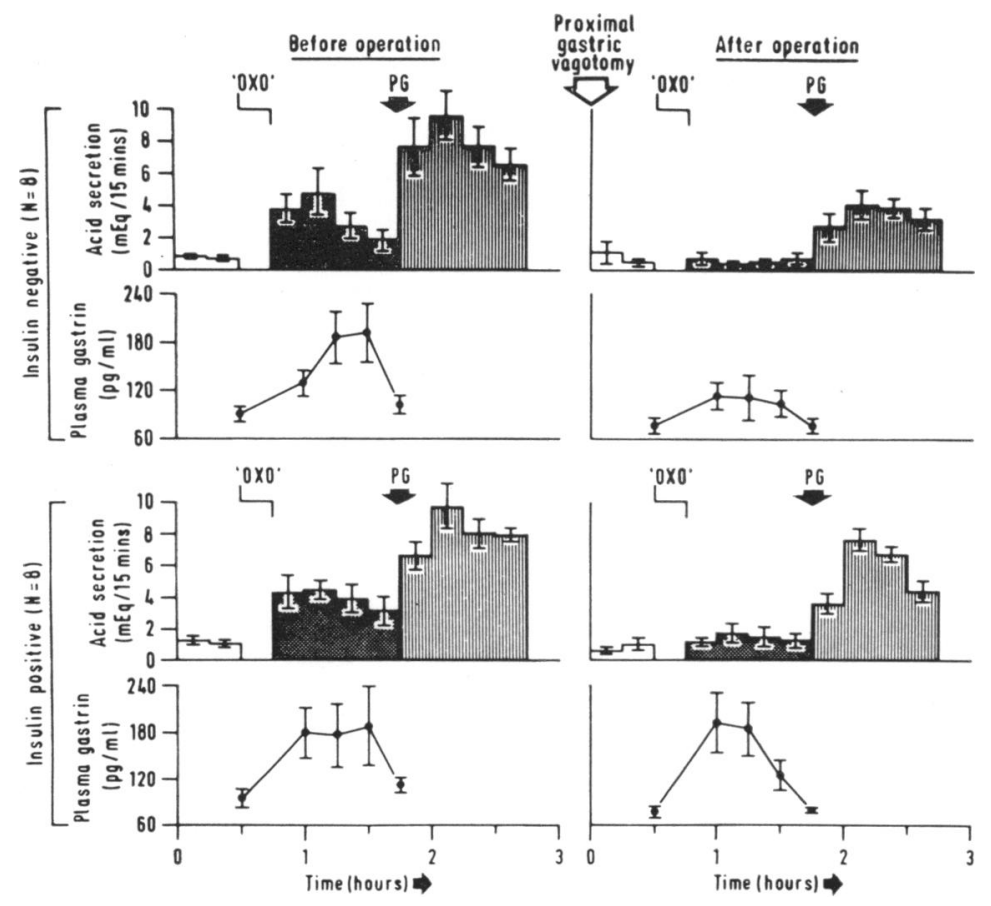

Fig. 2 Mean acid secretion and plasma gastrin levels in 16 patients before and after proximal gastric vagotomy, classified according to whether the post-operative insulin test was positive or negative. 
conceal the fact that the postoperative plasma gastrin response to Oxo was related to the result of the postoperative insulin test. This relationship is demonstrated by fig 2 in which the results have been examined according to whether vagotomy appeared complete or not. The postoperative insulin tests showed that there were eight insulin-positive and eight insulin-negative cases as judged by Hollander's (1948) criteria. The mean results for both pre- and postoperative tests for these two groups of patients are shown in fig 2, with the results of insulinnegative cases above and those of insulin-positive cases below. As in fig 1 the histograms indicate mean basal, Oxo-stimulated, and pentagastrin-stimulated acid secretion expressed in m-equiv/15 minutes and the points below the histograms indicate mean plasma gastrin levels. Table II shows numerical aspects of the data in the same format as was used in table $I$.

In the insulin-negative group basal acid secretion was at the rate of $3.12 \mathrm{~m}$-equiv $/ \mathrm{hr}$, and this was unchanged after operation. Oxo caused a marked secretion of acid in the tests done before operation; the peak acid output was, on average, 18.3 m-equiv/ $\mathrm{hr}$, and the total acid output was $13.04 \mathrm{~m}$-equiv/hr. After operation, however, Oxo never produced a stimulation of acid secretion. This is reflected in the peak and total acid outputs which were, on average, slightly below the basal level. The dramatic effect of operation on the acid secretory response to Oxo was statistically highly significant $(\mathrm{P}<0.005)$. The secretory response to pentagastrin was also reduced by operation; the mean peak acid secretion of 39.58 $\mathrm{m}$-equiv/hr before operation fell to $17.45 \mathrm{~m}$-equiv/hr afterwards $(P<0.01)$. Total acid secretion was similarly reduced from 31.38 to $14.00 \mathrm{~m}$-equiv/hr $(\mathrm{P}<0.001)$, a reduction of $55 \%$.

Operation produced no significant change in the basal plasma gastrin level which averaged $89 \mathrm{pg} / \mathrm{ml}$ before operation and $79 \mathrm{pg} / \mathrm{ml}$ afterwards. The peak plasma gastrin response following Oxo was, however, reduced from $237 \mathrm{pg} / \mathrm{ml}$ before operation to 135 $\mathrm{pg} / \mathrm{ml}$ afterwards. This fall was significant at the $5 \%$ level. Similarly, the overall plasma gastrin response was significantly reduced.

In the insulin-positive cases there was, again, no change in basal acid secretion. The peak response to Oxo fell from a preoperative value of 20.32 m-equiv/ $\mathrm{hr}$ to $6.97 \mathrm{~m}$-equiv $/ \mathrm{hr}(\mathrm{P}<0.005)$ and the total acid response to Oxo was also greatly diminished $(17 \cdot 30$ $\mathrm{m}$-equiv/hr to $5.50 \mathrm{~m}$-equiv/hr $(\mathrm{P}<0.01)$. The effect of these reductions was to yield the mean response in fig. 2 which is barely perceptible. On the other hand, the response to pentagastrin, though significantly reduced, was still substantial. Thus, the peak preoperative acid secretion of $37.92 \mathrm{~m}$-equiv/hr was reduced to $29.00 \mathrm{~m}$-equiv $/ \mathrm{hr}$ (but the difference failed to reach significance) and the total acid secretion fell from $32.30 \mathrm{~m}$-equiv/hr to $22.08 \mathrm{~m}$-equiv/ $\mathrm{hr}$, a reduction of $32 \%(\mathrm{P}<0.025)$. The basal plasma gastrin level of $94 \mathrm{pg} / \mathrm{ml}$ was not significantly changed at $79 \mathrm{pg} / \mathrm{ml}$ after operation, nor were the peak or overall plasma gastrin responses significantly reduced after operation.

Thus, the important difference between insulinpositive and insulin-negative groups was that the plasma gastrin response to Oxo was not significantly

\begin{tabular}{|c|c|c|c|c|c|c|c|}
\hline & & \multicolumn{3}{|c|}{ Mean Acid Secretion (m-equiv/hr) $\pm S E M$} & \multicolumn{3}{|c|}{ Plasma Gastrin Levels $(\mathrm{pg} / \mathrm{ml}) \pm S E M$} \\
\hline & & $\begin{array}{l}\text { Before } \\
\text { Operation }\end{array}$ & $\begin{array}{l}\text { After } \\
\text { Operation }\end{array}$ & $\begin{array}{l}\text { P Values }{ }^{1} \text { for } \\
\text { Pair Differences }\end{array}$ & $\begin{array}{l}\text { Before } \\
\text { Operation }\end{array}$ & $\begin{array}{l}\text { After } \\
\text { Operation }\end{array}$ & $\begin{array}{l}P \text { Values for } \\
\text { Pair Differences }\end{array}$ \\
\hline \multirow{2}{*}{$\begin{array}{l}\text { Postoperative } \\
\text { insulin test } \\
\text { negative }\end{array}$} & $\begin{array}{l}\text { Basal } \\
\text { Peak after Oxo } \\
\text { Total after Oxo }\end{array}$ & $\begin{array}{r}3 \cdot 12 \pm 0.62 \\
18 \cdot 30 \pm 4 \cdot 53 \\
13.04 \pm 3 \cdot 16\end{array}$ & $\begin{array}{l}3 \cdot 13 \pm 1 \cdot 84 \\
2 \cdot 70 \pm 0.94 \\
2 \cdot 36 \pm 0.97\end{array}$ & $\begin{array}{l}\text { NS } \\
P<0.005 \\
P<0.005\end{array}$ & $\begin{array}{r}89 \cdot 0 \pm 10 \cdot 7 \\
236 \cdot 6 \pm 33 \cdot 1 \\
604.6 \pm 61 \cdot 4\end{array}$ & $\begin{array}{r}78.9 \pm 14.4 \\
134.9 \pm 26.8 \\
406.5 \pm 63.4\end{array}$ & $\begin{array}{l}\text { NS } \\
P<0.05 \\
P<0.05\end{array}$ \\
\hline & $\begin{array}{l}\text { Peak after } \\
\text { pentagastrin } \\
\text { Total after } \\
\text { pentagastrin }\end{array}$ & $39 \cdot 58 \pm 5 \cdot 33$ & $\begin{array}{l}17 \cdot 45 \pm 2.79 \\
14.00 \pm 2.53\end{array}$ & $P<0.001$ & & & \\
\hline \multirow{2}{*}{$\begin{array}{l}\text { Postoperative } \\
\text { insulin test } \\
\text { positive }\end{array}$} & $\begin{array}{l}\text { Basal } \\
\text { Peak after Oxo } \\
\text { Total after Oxo }\end{array}$ & $\begin{array}{r}4.79 \pm 1.21 \\
20.32 \pm 2.85 \\
17.30 \pm 3.01\end{array}$ & $\begin{array}{l}3 \cdot 10 \pm 1.06 \\
6.97 \pm 2 \cdot 11 \\
5.50 \pm 1 \cdot 80\end{array}$ & $\begin{array}{l}\text { NS } \\
P<0.005 \\
P<0.01\end{array}$ & $\begin{array}{r}94 \cdot 4 \pm 12 \cdot 3 \\
262 \cdot 5 \pm 41 \cdot 0 \\
657 \cdot 2 \pm 94 \cdot 7\end{array}$ & $\begin{array}{r}78 \cdot 5 \pm 7 \cdot 3 \\
229 \cdot 4 \pm 42 \cdot 2 \\
580 \cdot 8 \pm 75 \cdot 3\end{array}$ & $\begin{array}{l}\text { NS } \\
\text { NS } \\
\text { NS }\end{array}$ \\
\hline & $\begin{array}{l}\text { Peak after } \\
\text { pentagastrin } \\
\text { Total afier } \\
\text { pentagastrin }\end{array}$ & $\begin{array}{l}37.92 \pm 3.29 \\
32.30 \pm 2.68\end{array}$ & $\begin{aligned} 29.00 & \pm 1.87 \\
22.08 & \pm 2.00\end{aligned}$ & $\begin{array}{l}\text { NS } \\
\mathrm{P}<0.025\end{array}$ & & & \\
\hline
\end{tabular}

Table II Results of acid secretion tests and plasma gastrin estimations in 16 patients before and after proximal gastric vagotomy classified according to the results of postoperative insulin tests

'P values calculated for one-tail $t$ tests. 
changed postoperatively in the insulin-positive group whereas it was significantly reduced postoperatively in the insulin-negative group. This difference between the two groups appears to be real since they were well matched preoperatively with respect to basal secretion, acid secretory response to Oxo, acid secretory reponse to pentagastrin, and plasma gastrin response to Oxo.

\section{Discussion}

There is no general agreement about the effect of vagotomy on fasting plasma gastrin levels. The present study re-examines this problem and attempts to extend the observations by investigating the effects of antral stimulation before and after vagotomy. In previous reports the effect of vagotomy could not be studied in isolation since other procedures such as antrectomy or gastric drainage were also performed. The present observations were made on patients in whom the operation consisted solely of proximal gastric vagotomy (highly selective vagotomy). This operation is intended to denervate only the parietal cells, leaving antral innervation undisturbed and obviating the need for gastric drainage. The observations therefore provided a unique opportunity to investigate the effects of vagotomizing the parietal cell mass.

The mean fasting plasma gastrin levels observed in the present study are not dissimilar to those of McGuigan, and Trudeau(1972), who found that in 24 patients a mean fasting serum gastrin of $98 \mathrm{pg} / \mathrm{ml}$ before operation was not significantly changed at $123 \mathrm{pg} / \mathrm{ml}$ after truncal vagotomy and pyloroplasty. Similarly, Stadil (1972) obtained values of $104 \mathrm{pg} / \mathrm{ml}$ in 23 unoperated patients and $103 \mathrm{pg} / \mathrm{ml}$ in 19 patients following truncal vagotomy and pyloroplasty. However, other workers have found that vagotomy produced marked changes in the fasting serum or plasma gastrin level. Byrnes et al (1970) noted that after complete truncal vagotomy there was, in eight patients, a reduction in the fasting serum gastrin to a level below that found in normals or in patients with duodenal ulcer. In contrast, Hansky and his coworkers found that vagotomy raised the fasting serum gastrin level from a mean of $15.7 \pm 1.5 \mathrm{pg} / \mathrm{ml}$ in 72 unoperated duodenal ulcer patients (Korman, Soveny, and Hansky, 1971) to $52 \pm 5.7 \mathrm{pg} / \mathrm{ml}$ in 30 patients following selective vagotomy and (usually) pyloroplasty (Korman et al 1972a). After truncal vagotomy and pylorectomy an even greater rise occurred to a level of $84 \pm 7.9 \mathrm{pg} / \mathrm{ml}$ (Korman, et al, 1972b). It is difficult to account for these discrepancies between the findings of different workers. Perhaps the results of Byrnes et al (1970) may be explained by the fact that they used an antiserum raised against pentagastrin whereas all other workers have raised their antisera against gastrin heptadecapeptide. Plasma gastrin is known not to be a single molecular species (Yalow and Berson, 1970) and it seems likely that different antibodies detect different species of the hormone. This may also explain Hansky's results if he has produced antibodies of different specificity to those produced by McGuigan and Trudeau (1972), Stadil (1972), and ourselves. If this is so, the indications are that gastrin in the plasma may consist of several components whose concentrations vary independently. Another possibility is that divergent results are due to differences in the plasma gastrin level produced by different types of vagotomy or by associated drainage procedures. However, it is impossible at present to discern the factors which might reconcile all the published data.

Despite these difficulties in interpreting published work on basal plasma gastrin levels, it is generally believed that an increased output of gastrin from the antrum is important in postprandial stimulation of acid secretion by the fundus. Stimulation of gastrin release from the antrum is reflected in increased levels of plasma gastrin measured by radioimmunoassay. We have recently compared gastrin levels following a normal meal with those following administration of a liquid meat extract. The meat extract (Oxo) stimulation test has been used as a measure of antral function (Giles and Clark, 1966) and a recent study showed that Oxo was an excellent stimulus for gastrin release, producing a peak elevation in plasma gastrin equivalent to that following a standard meal (Wyllie et al, 1972). One might expect that these plasma gastrin responses to Oxo would be unchanged following proximal gastric vagotomy since the operation is intended to retain antral innervation and preserve normal antral function.

This was found in eight cases with positive postoperative insulin tests. However, insulin-negative cases showed a different pattern. In only one of these was the postoperative plasma gastrin response similar to the preoperative response. All the others showed gross postoperative depression of the plasma gastrin response, amounting to abolition in four cases. It would seem that postoperative retention of a plasma gastrin response to Oxo was almost always associated with a positive acid-secretory response to insulin. Such positive responses to insulin are usually considered to imply incomplete division of the vagal nerves. However, proximal gastric vagotomy sets out to preserve vagal innervation of the antrum. It thus appears that preservation of the antral nerves may be responsible for both gastrin release by Oxo and acid secretion in response to insulin. It has already been suggested that a positive Hollander test after 
proximal gastric vagotomy may not carry the same risk of recurrent ulceration as an incomplete truncal vagotomy (Johnston, personal communication).

Alternative explanations for our results must be considered. Preservation of both antral and fundic vagal nerve fibres might explain the concurrence of positive Oxo tests and positive insulin tests if these responses were due to preservation of different nerve fibres. In such a case we would expect positive Oxo tests to be randomly associated with positive insulin tests. A calculation of the exact binomial probability of the distribution of results actually found shows that it cannot reasonably be ascribed to chance $(P<0.001)$. Another possibility is that Oxo stimulates gastric secretion partly by release of antral gastrin and partly by eliciting a vagal reflex which releases further gastrin. Whatever the explanation of the results there is clearly a relationship postoperatively between the release of gastrin by Oxo and the insulin response.

Previous observations on plasma gastrin levels in response to antral stimulation have been made by Forrester and Ganguli (1970), who employed meat extract. However, these workers confined their studies to normal subjects. Of greater relevance is the work of Korman et al (1972b), who used a standard meal to stimulate antral gastrin release in duodenal ulcer patients. This precluded simultaneous measurement of gastric acid secretion. Their observations were confined to subjects examined at least one year after operation and it was found that the rise in plasma gastrin in response to a meal was considerably greater after operation. Truncal vagotomy gave higher responses than selective vagotomy, suggesting to these authors that there might be extragastric vagal fibres which inhibit gastrin release. Clearly, these findings are quite different from the present results and further investigation is needed. Perhaps the differences are related to the type of vagotomy performed or to the length of the postoperative period before testing. There is evidence that after proximal gastric vagotomy the incidence of positive insulin tests increases with the passage of time, implying a recovery of nerve function (Kragelund, Amdrup, Goligher, Humphrey, Smith, Wilkinson, and Johnston, 1971). The acid response to Oxo appears to behave similarly. It is frequently absent in tests done immediately after operation (Johnston, personal communication) and it is minimal even in patients who preserve the ability to release gastrin postoperatively (see fig 2 and table II). One year after operation it is usually present though the response is only about $50 \%$ of the preoperative value (Johnston, Humphrey, Smith, and Wilkinson, 1971). These results are usually explained by supposing that in the immediate postoperative phase the parietal cells are insensitive to gastrin as was shown by Giles (1968). This is supported (in the present data) by the finding that acid secretory responses to pentagastrin were significantly reduced postoperatively.

The present results allow us to offer possible explanations for the return of acid secretion in Oxo tests performed in the late postoperative period. It is possible that the release of gastrin in response to Oxo is depressed in the early postoperative phase and then becomes augmented; this would fit with Hansky's data. On the other hand, the intimate relationship between antral function and vagal function shown by the present results suggests that recovery of function might be due to vagal reinnervation, perhaps by collateral nerve sprouting (Clark, 1964). The problem is of some importance, since the long-term results of proximal gastric vagotomy are unknown, and the prognostic value of insulin and antral function tests is far from clear.

We are indebted to Miss Jeannie Butler and Miss Lesley A. Gruby for excellent technical help.

\section{References}

Byrnes, D. J., Lazarus, L., and Young, J. D. (1970). Effect of vagotomy on serum gastrin in patients with duodenal ulceration. Aust. Ann. Med., 3, 240-243.

Clark, C. G. (1964). Recovery of gastric function after incomplete vagotomy. Brit. J. Surg., 51, 539-542.

Clarke, R. J. (1971). A randomized trial of selective and parietal cell vagotomy without a drainage procedure. (Abstr.) Brit. J. Surg., $58,870-871$.

Forrester, J. M., and Ganguli, P. C. (1970). The effect of meat extract (Oxo) on plasma gastrin concentration in human subjects. $J$. Physiol. (Lond.), 211, 33P-35P.

Giles, G. R. (1968). A Study into Gastric Acid Secretion in man and Its Effect on the Lower Oesophagus. MD Thesis, University of Manchester.

Giles, G. R., and Clark, C. G. (1966). Gastric secretion stimulated by meat extract in man: a test of antral function. Scand. $J$. Gastroent., 1, 159-166.

Hassan, M. A., and Hobsley, M. (1970). Positioning of subject and of nasogastric tube during a gastric secretion study. Brit. med.J., $1,458-460$.

Hollander, F. (1948). Laboratory procedures in the study of vagotomy (with particular reference to the insulin test). Gastroenterology, 11, 419-425.

Johnston, D., Humphrey, C. S., Smith, R. B., and Wilkinson, A. R. (1971). Should the gastric antrum be vagally denervated if it is well drained and in the acid stream? Brit. J. Surg., 58, 725-731.

Korman, M. G., Hansky, J., Coupland, G. A. E., and Cumberland, V. H. (1972a). Serum gastrin in duodenal ulcer. IV. Effect of selective gastric vagotomy. Gut, 13, 163-165.

Korman, M. G., Hansky, J., and Scott, P. R. (1972b). Serum gastrin in duodenal ulcer. Part 3. Influence of vagotomy and pylorectomy. Gut, 13, 39-42.

Korman, M. G., Soveny, C., and Hansky, J. (1971). Serum gastrin in duodenal ulcer. Part 1. Basal levels and effect of food and atropine. Gut, 12, 899-902.

Kragelund, E., Amdrup, E., Goligher, J. C., Humphrey, C. S., Smith, R. B., Wilkinson, A. R., and Johnston, D. (1971). The insulin test after highly selective vagotomy without drainage for duodenal ulcer. (Abstr.) Brit. J. Surg., 58, 871.

McGuigan, J. E., and Trudeau, W. L. (1972). Serum gastrin: effect of vagotomy with pyloroplasty or with antrectomy. New Engl. J. Med., 286, 184-188.

Stadil, F. (1972). Effect of vagotomy on gastrin release during insulin 
hypoglycaemia in ulcer patients. Scand. J. Gastroent., 7, 225231

Wastell, C., MacNaughton, J. I., Colin, J. F., and Gleeson, J. (1971). Gastric secretion and emptying before and after parietal cell vagotomy, with and without pyloroplasty. (Abstr.) Brit. J. Surg., 58, 871.

Welbourn, R. B., and Burnes, G. P. (1964). The choice of operation for duodenal ulcer on the basis of pre-operative gastric secretory studies. In Proceedings of the 7th International Congress of Gastroenterology, p. 163.

Wyllie, J. H., Boulos, P. B., Lewin, M. R., Stagg, B. H., and Clark, C. G. (1972). Plasma gastrin and acid secretion in man following stimulation by food, meat extract, and insulin. Gut, 13, 887-893.

Yalow, R. S., and Berson, S. A. (1970). Size and charge distinctions between endogenous human plasma gastrin in peripheral blood and heptadecapeptide gastrins. Gastroenterology, 58, 609-615. 